\title{
Hubungan antara Kompetensi Profesional Guru dan Budaya Organisasi dengan Kinerja Guru di SD Gugus 10 Kota Prabumulih
}

\author{
Darusman $^{\varpi 1}$, Edi Harapan ${ }^{2}$, Tahrun $^{3}$ \\ (1) Sekolah Dasar Negeri 25 Kota Prabumulih \\ $(2,3)$ Universitas PGRI Palembang
}

$\triangle$ Corresponding author

[mandarus988@gmail.com]

\begin{abstract}
Abstrak
Tujuan penelitian ini untuk mengidentifikasi kontribusi variabel profesionalisme dan budaya organisasi di sekolah terhadap kinerja guru SD di Gugus 10 Kota Prabumulih. Jenis penelitian ini adalah penelitian korelasional. Teknik analisis data dilakukan dengan bantuan program SPSS. Hasil dari penelitian ini dapat disimpulkan bahwa: 1) terdapat hubungan signifikan antara kompetensi professional dengan kinerja guru; 2) terdapat hubungan signifikan antara budaya organisasi di sekolah dengan kinerja guru SD di Gugus 10 Kota Prabumulih; 3) terdapat hubungan signifikan antara kompetensi profesional dan budaya organisasi dengan kinerja guru SD di Gugus 10 Kota Prabumulih.
\end{abstract}

Kata Kunci: Kompetensi Profesional Guru; Budaya Organisasi; Kinerja Guru

\begin{abstract}
The purpose of this study was to identify the contribution of professionalism and organizational culture variables in schools to the performance of elementary school teachers in Cluster 10 Prabumulih City. This type of research is correlational research. The data analysis technique was carried out with the help of the SPSS program. The results of this study concluded that: 1) there is a significant relationship between professional competence and teacher performance; 2) there is a significant relationship between organizational culture in schools and the performance of elementary school teachers in Cluster 10 Prabumulih City; 3 ) there is a significant relationship between professional competence and organizational culture with the performance of elementary school teachers in Cluster 10 Prabumulih City.
\end{abstract}

Keyword: Teacher Professional Competence; Organizational Culture; Teacher Performance

\section{PENDAHULUAN}

Tidak dapat dipungkiri bahwa dunia pendidikan menjadi pilar penting yang memiliki peran strategis dalam membina dan mengembangkan karakter bangsa dalam rangka mencerdaskan kehidupan bangsa. Pendidikan menjadi investasi jangka panjang yang hasilnya tidak secara langsung dapat diketahui. Hasil pendidikan membutuhkan waktu yang panjang, sepanjang hayat, menyentuh berbagai sendi kehidupan sehingga menjadi jati diri untuk kemajuan, keadilan, dan kemakmuran bangsa.

Education is the most important indicator of a country's progress (Asvio et al, 2019). Education is a conscious effort to build quality human resources to compete (Tobari et al, 2018). Quality human resources are more important than the wealth of natural resources, because the wealth of natural resources cannot guarantee the welfare and success of a nation (Asvio et al, 2019).

Agenda penting yang perlu mendapat perhatian dalam dunia pendidikan antara lain masalah mutu pendidikan di Indonesia. Kualitas pendidikan Indonesia ditenggarai masih memprihatinkan apalagi dibandingkan dengan negara maju bahkan negara berkembang lainnya. Hal yang demikian tentu sangat berpengaruh terhadap kualitas sumber daya manusia Indonesia. Mutu pendidikan yang rendah pada akhirnya menyebabkan sumber daya manusia Indonesia kurang kompetitif terutama dalam menghadapi globalisasi yang menghendaki sumber daya manusia Indonesia memiliki daya saing tinggi di era persaingan bebas.

Dalam Undang - Undang Nomor 14 Tahun 2005 tentang Guru dan Dosen pada pasal 1 antara lain dikatakan bahwa guru adalah pendidik profesional dengan tugas utama mendidik, mengajar, membimbing, mengarahkan, melatih, menilai, dan mengevaluasi peserta didik pada pendidikan usia dini jalur pendidikan formal, pendidikan dasar, dan pendidikan menengah sesuai dengan peraturan perundangan.Jelaslah bahwa peran seorang guru dalam dunia pendidikan sangatlah urgen. Dapat dikatakan bahwa guru merupakan panji terdepan yang akan menghadapi peserta didik secara langsung dengan beragam permasalahannya. Betapa 
pun pesatnya kemajuan teknologi di abad informasi ini, peran guru belum tergantikan. Guru tetap memiliki peran utama dalam dunia pendidikan.

Semakin tingginya tuntutan terhadap dunia pendidikan menyebabkan tuntutan terhadap profesionalisme guru juga semakin meningkat. Masyarakat sangat mengharapkan sosok guru profesional bagi peserta didik. Profesionalitas guru dalam proses pendidikan memiliki peranan yang sangat strategis dalam membimbing peserta didik ke arah kedewasaan, kematangan menuju kemandirian. Sebagai tenaga profesional, tugas guru bukan hanya mengajar, menyampaikan materi pelajaran sesuai dengan tanggung jawabnya, melainkan juga sebagai seorang pendidik. Sebagai seorang pendidik, tugas guru berkaitan dengan pembentukan sikap dan perilaku peserta didik untuk membentuk individu berkarakter baik sebagai individu maupun sebagai anggota masyarakat, bangsa, negara, dan agama.

Dari uraian di atas, kita dapat mengambil kesimpulan bahwa guru merupakan salah satu faktor yang mempengaruhi kualitas pendidikan. Di tangan guru yang profesional, program-programdalam dunia pendidikan dapat lebih mudah dicapai. Untuk itu, dibutuhkan suatu mekanisme dan usaha yang memungkinkan sekolah dapat mengetahui kinerja guru yang mengabdikan diri pada suatu unit kerja.

Kinerja guru itu sendiri diartikan sebagai tingkat keberhasilan guru dalam melaksanakan tugas pendidikan sesuai dengan tugas dan wewenangnya berdasarkan standar yang telah ditetapkan selama periode tertentu dalam rangka pencapaian tujuan pendidikan (Barnawi, 2014). Secara lebih khusus, kinerja mengajar guru merupakan prestasi yang dicapai oleh guru dalam melaksanakan tugasnya selama periode tertentu dengan indikator yang terdiri atas: penguasan bahan ajar, kemampuan mengelola pembelajaran, dan komitmen menjalankan tugas (Suhayati, 2013).

Salah satu faktor yang mempengaruhi kinerja guru adalah kompetensi. Kompetensi yang harus dimiliki oleh guru sesuai dengan UU RI No. 14 Tahun 2005 tentang Guru dan Dosen, pasal 10, ayat 1 adalah kompetensi pedagogik, kompetensi kepribadian, kompetensi profesional, dan kompetensi sosial.

Kompetensi profesional merupakan salah satu modal yang sangat perlu dimiliki guru. Kompetensi ini berkaitan dengan penguasaan bahan materi pelajaran yang akan disampaikan dalam pembelajaran. Tugas guru memang berkaitan dengan materi pelajaran sebagai pihak yang akan memfasilitasi kegiatan untuk penguasaan materi pelajaran tersebut.

Pada hakikatnya sekolah adalah suatu organisasi. Organisasi itu sendiri dapat diartikan sebagai tata susunan yang mengatur hubungan antarpihak dan komponen dalam suatu lingkungan kerja. Secara lebih khusus, organisasi sekolah merupakan suatu kesatuan yang komponen pembentuknya berinteraksi dalam mencapai tujuan pendidikan yang telah ditetapkan sebelumnya (Suharsaputra, 2018).

Dalam organisasi sekolah ada dua dimensi penting yang sangat berperan di dalamnya yaitu dimensi struktur dan dimensi kultur. Dimensi struktur berkaitan dengan posisi, peran, dan tugas, setiap komponen yang ada di sekolah. Sebagai suatu organisasi, sekolah dibentuk oleh komponen-komponen yang ada dengan kapasitas tugas dan tanggung jawab yang dibebankan kepadanya. Dimensi kultur berkaitan dengan nilai, norma, sikap, dan perilaku komponen-komponen yang ada di sekolah dalam mendukung kerangka kerja yang telah ditetapkan sebelumnya. Hal ini sesuai dengan pendapat Suharsaputra (2018). Salah satu aspek yang berkaitan dengan dimensi kultur organisasi sekolah adalah budaya organisasi. Budaya organisasi mengendalikan anggota organisasi dalam berinteraksi dengan berbagai pihak. Fattah (2019) mengatakan bahwa budaya organisasi adalah seperangkat nilai-nilai bersama dan norma-norma yang mengendalikan anggota organisasi berinteraksi satu sama lain dengan pemasok, pelanggan, dan orang lain di luar organisasi. Dalam redaksi bahasa yang berbeda, menurut Raharjo (2016) bahwa budaya yang diciptakan organisasi mempengaruhi perilaku karyawan dan pelaksanaan budaya organisasi dipengaruhi oleh budaya yang dibawa oleh pribadi-pribadi dalam berorganisasi. Budaya organisasi sangat berpengaruh terhadap perilaku semua anggota organisasi. Sudah menjadi kewajiban organisasilah untuk membangun arah dan strategi pembentukan budaya yang kuat sehingga dipatuhi oleh semua anggotanya. Bahkan, menurut Moorhead dalam Fattah (2019) bahwa budaya organisasi adalah suatu kekuatan yang tidak terlihat,tetapi dapat mempengaruhi pikiran, perasaan, dan tindakan orang-orang yang bekerja dalam suatu organisasi. Budaya organisasi berpengaruh langsung terhadap orang-orang dalam organisasi untuk melakukan suatu yang benar.

Kinerja guru yang menggambarkan pencapaian guru dalam melaksanakan tugasnya, dipengaruhi antara lain oleh modal dasar yang dimilikinya untuk dapat bekerja sebagai tenaga profesional. Selain itu, juga dipengaruhi oleh pola pikir dan perilaku individu dalam berinteraksi dengan segenap komponen yang ada di sekolah. Bertitik tolak dari hal itu dan uraian sebelumnya, pada akhirnya penulis tertarik untuk meneliti hubungan antara kompetensi profesional guru dan budaya organisasi dengan kinerja guru di SD Gugus 10 Kota Prabumulih.

\section{METODE PENELITIAN}

Jenis penelitian ini adalah penelitian korelasional, yaitu merupakan penelitian untuk mengetahui korelasi variabel-variabel yang berbeda dalam suatu populasi, untuk mengetahui seberapa besar hubungan variabel bebas terhadap variabel terikat. Jadi, dalam penelitian ini kompetensi profesional dan budaya 
organisasi sebagai variabel bebas, sedangkan kinerja guru sebagai variabel terikat. Metode penelitian analisis korelasi dipilih karena akan mempelajari hubungan dua variabel atau lebih, yakni hubungan variasi dalam satu konsensus dengan variasi dalam konsensus lain.

Penelitian dilaksanakan pada 8 Sekolah Dasar Gugus 10 Kota Prabumulih sebanyak 105 orang guru sebagai sampel dari populasi sebanyak 143 orang guru dengan menggunakan instrumen berupa angket atau kuesioner untuk mengukur kompetensi Profesional Guru dan Budaya Organisasi terhadap Kinerja Guru. Sebelum dilaksanakan penelitian, akan diuji coba instrumen berupa angket atau kuisioner yang akan diisi oleh 30 orang guru yang masing-masing dari 8 sekolah yang akan dilaksanakan penelitian. Teknik analisis data dilakukan dengan bantuan program SPSS.

\section{HASIL DAN PEMBAHASAN}

Hasil analisis bivariat memperlihatkan bahwa hubungan antara profesionalisme guru (Variabel X1) dengan kinerja guru (Variavel $\mathrm{Y}$ ) adalah sebesar 0,899 . Nilai korelasi ini merupakan hubungan yang sangat kuat dan sangat signifikan (sig $=0,000<0,05$ atau 0,01 ). Hasil analisis ini memutuskan untuk menerima hipotesis H.1.a dan menolak H.1.b. Dengan kata lain dapat dinyatkan bahwa ada hubungan positif dan signifikan antara kompetensi profesional dengan kinerja guru, khusunya guru-guru SD di Gugus 10 Kota Prabumulih.

Polah hubungan posisif ini didukung oleh nilai profesional yang tinggi di kalangan guru-guru SD di Rayon 10 Kota Prabumulih. Nampaknya predikat sangat baik dan baik dari sub variabel komitmen/konsistensi (98,10\%; 1,9\%), tanggungjawab (98,10\%; 1,9\%), keterbukaan $(96,19 \% ; 3,81 \%)$, orientasi terhadap reward (98,10\%; 1,9\%), dan kemampuan/kreativitas (95,24\%; 4,76\%) sangat menyokong peningkatan kinerja. Keadaan ini menunjukkan semua guru-guru SD dalam Gugus 10 Kota Prabumulih $(n=105)$ berada dalam kategori sangat baik dan baik.

Guru adalah pendidik profesional dengan tugas utama mendidik, mengajar, membimbing, mengarahkan, melatih, menilai, dan mengevaluasi peserta didik pada pendidikan usia dini jalur pendidikan formal, pendidikan dasar, dan pendidikan menengah sesuai dengan peraturan perundangan (UU No. 14 Tahun 2005). Berbagai kriteria yang menyatakan keprofesionalan seorang guru dalam melaksanakan tugasnya.

Berdasarkan temuan terlihat secara empiris membuktikan bahwa kompetensi profesional guru merupakan salah satu faktor yang mempengaruhi peningkatan kinerja guru. $\mathrm{Hal}$ ini sejalan dengan pendapat Muklis dalam Saputra (2011). Menurut Syah (2010) bahwa guru yang berkompeten dan profesional adalah guru diharapkan memiliki kompetensi kognitif, kompetensi afektif, dan kompetensi psikomotorik dalam menjalankan kewenangannya sebagai guru. Hasil dari penelitian ini menunjukkan sub variabel komitmen, tanggungjawab, keterbukaan, orienasi terhadap reward, dan kemampuan ataukreativitas merupakan apsek yang telah memenuhi kriteria ini.

Seorang guru yang baik haruslah memiliki pengetahuan tentang bagaimana mengajarkan bahan ajar kepada siswa. Pengetahuan-pengetahuan tersebut dapat menuntun guru untuk merangkai situasi pembelajaran sesuai kebutuhan siswa. Pengetahuan tersebut dikenal dengan pengetahuan konten pedagogi (Anwar dan Madang, 2017). Kompetensi kognitif dan psikomotorik ini terlihat dari kemampuan menjadi pamong bagi peserta didik, kolaborasi dengan teman sejawat, mendiskusikan strategi baru dalam mengajar, mengajar dengan baik, menganalisis data para siswa, memotivasi peserta didik, memiliki keahlian khusus, dan memeiliki kompetensi terhadap mata pelajaran yang diampul. Ketujuh aspek ini umumnya berada dalam kategori sangat baik dan baik sehingga pada gilirannya menyebabkan kompetensi kognitif dan pedagogik menjadi profesional untuk tugas sebagai seorang guru.

Selanjutnya kompetensi afektif guru-guru SD di Gugus 10 Kota Prabumulih terlihat dari diperlihatkan dari sub variabel komitmen, tanggungjawab, keterbukaan, dan orientasi terhadap reward. Komponen sikap menurut Alma (2010) merupakan perasaan diri yang meliputi self concepts, self eficary, attitude of selfacceptance, dan pandangan seorang guru terhadap kualitas dirinya. Oleh karena ketiga sub-variabel ini telah memenuhi kriteria sangat baik dan baik maka aspek sikap profesionalisme guru-guru SD di Gugus 10 Kota Prabumulih sudah dikatakan sangat baik dan baik.

Menurut Majid (2005) bahwa kompetensi yang dimiliki oleh setiap guru akan menunjukkan kualitas guru dalam mengajar. Kompetensi tersebut antaralain dapat diwujudkan dalam bentuk penguasaan pengetahuan dan profesional dalam menjalankan fungsinya sebagai guru. Berdasarkan ketiga aspek progesionalisme guru yaitu kognitif, afeksif, dan psikomotorik maka terlihat bahwa kompetensi profesionalisme guru-guru SD di Gugus 10 Kota Prabumuliah sudah dikatakan memadai. Pertimbangan ini mengacu kepada Alma (2010) yang menyatakan bahwa seorang guru yang profesional adalah seorang yang melaksanakan pekerjaannya sesuai dengan profesinya yaitu mempunyai tanggungjawab sebagai pengajar, pendidik, pembimbing, administrator kelas, pengembang kurikulum, pengembang profesi, dan membina hubungan dengan masyarakat. Komponen-komponen ini telah mendapatkan kategori yang sangat baik dan baik pada setiap item dalam setiap sub-varibel. Dengan adanya kategori yang sangat baik dan baik inilah yang menyebabkan kinerja guru menjadi sangat baik dan baik pula. Selanjutnya dengan adanya sinergisme diantara 
dua variabel yaitu variabel kompetensi profesionalisme dan variabel kinerja guru menyebabkan hubungan berlangsung linear positif. Dalam pengertian lain, peningkatan perofesionalisme akan diikuti pengingkatan kinerja guru yang dalam perhitungan inferensia akan meningkat sebesar 0,329 bila skala peningkatan diasumsikan 1 skala.

Selanjutnya pengujian hipotesis 2 (H.2) menunjukkan adanya hubungan positif dan signifikan antara budaya organisasi di sekolah dengan kinerja guru guru-guru SD di Gugus 10 Kota Prabumulih. Hubungan ini ditunjukkan oleh nilai $r=0,886$ yang berarti hubungan tersebut sangat kuat dan nilai signifikan $p=0,000<$ 0,05 yang berarti hubungan itu sangat signifikan. Dengan demikian dapat diputuskan untuk menerima H.2.a dan tolak H.2.o sehingga dapat pula dinyatakan adanya hubungan positif dan signifikan antara budaya organisasi dan kinerja guru.

Budaya organisasi di sekolah sangat diperlukan oleh seorang guru dalam menjalankan tugasnya. Budaya organisasi yang diukur dalam penelitian ini adalah dua subvariabel yaitu adaptasi eksternal dan integrasi internal. Secara umum kedua sub-variabel ini berada dalam kategori yang sangat baik $(99,05 \%)$ dan baik $(0,95 \%)$. Oleh karena organisasi adalah sproduk kebudayaan modern manusia yang diarahkan kepada suatu kepemiilikan sistem kerja yang memungkinkan tercapainya keinginan, kerjasama dan tujuan manusia dengan sebaik-baiknya maka kedua sub-variabel ini sangat penting dalam menyokong kinerja guru.

Dari sub-variabel adaptasi eksternal terlihat bahwa guru-guru SD di gugus 10 Kota Prabumulih telah memahami dan melaksanakan konsensus pentingnya keyakinan terhadap misi dan strategi sekolah, konsensus yang jelas untuk mencapai tujuan sekolah, konsensus tentang cara untuk mengevaluasi diri dalam rangka mencapai tujuan, dan konsensus untuk kegagalan. Aspek-aspek ini umumnya berad dalam kategori sangat baik. Menurut Suwarto dan Koesnarto (2009) upaya ini merupakan upaya Individu berfokus pada hasil, bukan pada teknik dan proses untuk mencapai hasil. Dalam budaya organisasi, diharapkan individu dapat berinisiatif bukan bersifat menunggu dan dapat mengambil tindakan sesegera mungkin atas masalah-masalah yang dihadapi dalam organisasi. Tegasnya, baik individu maupun kelompok kerja memiliki kontribusi penting dalam menentukan efektivitas organisasi karena sebagai sistem terbuka yang berinteraksi dengan lingkungan eksternal sehingga proses mencapai tujuan dapat menjadi optimal optimal.

Dari sub-variabel integrasi internal memperlihatkan pengelolaan sikap siswa dalam bertindak, berbahasa, berbusana, pengelolaan kenakalan siswa, dan prestasi siswa. Selaian itu guru menghadiri pertemuan-pertemuan, pelayanan tamu, tata tertib, penyesiaan sarana dan prasaran belajar, dan penerapan sanksi. Semua aspek ini umumnya berada dalam kategori sangat baik. Dalam konteks ini Suwarto dan Koesnarto (2009) mengungkapkan ciri busaya organisasi yaitu memperhitungkan efek hasil pada orang-orang di dalam organisasi dimana setiap individu dalam organisasi diharapkan dapat berkontribusi untuk kemajuan organisasi dan tidak menyalahkan apabila organisasi tetap mempertahankan hal-hal yang sudah dianggap baik walaupun, hal-hal yang bersifat up date tetap menjadi perhatian.

Hubungan positif dan signifikan antara budaya organisasi di sekolah dengan kinerja guru-guru SD di Gugus 10 Kota Prabumulih sebetulnya disokong oleh beberapa hal. Fungsi kepemimpinan dari kepala sekolah sangat berperan dalam konteks ini. Budaya organisasi yang benar-benar dikelola sebagai alat manajemen akan berpengaruh dan menjadi pendorong bagi karyawan untuk berparilaku positif, dedikatif, dan produktif (Sutrisno, 2019). Keutamaan budaya organisasi merupakan pengendali dan arah dalam membentuk sikap dan perilaku manusia yang melibatkan diri dalam suatu kegiatan organisasi. Dengan demikian dapatlah dikatakan bahawa budaya organisasi di sekolah berperan sebagai perekat sosial yang membantu mempersatukan organisasi sekolah sehingga menjadi pedoman budaya nilai untuk membentuk sikap dalam organisasi sekolah itu sendiri.

Pengujian hipotesis $3(\mathrm{H} .3)$ menunjukkan adanya hubungan kompetensi profesionalisme dan budaya organisasi di sekolah dengan kinerja guru SD di Gugus 10 Kota Prabumulih secara simultan (terima H.3.a dan tolak H.3.o). Pengaruh ini terlihat pada model regresi $(p=0.000<0,05)$ dimana variabel bebas kompetensi profesional dan budaya organisasi di sekolah berhubungan sangat erat dan signifikan dengan variabel terikat kinerja guru. Aspek yang sangat penting perlu dikemukakan adalah sinergisme diantara dua variabel yaitu variabel kompetensi profesionalisme dan variabel kinerja guru menyebabkan hubungan berlangsung linear positif $(r=0,930)$. Akhirnya secara simultan kompetensi profesionalisme dan budaya organisasi di sekolah secara simultan memberikan kontribusi sebesar $86,3 \%$ terhadap peningkatan kinerja sekolah bila skala peningkatan diasumsikan 1 skala.

Kinerja adalah hasil kerja yang dapat dicapai oleh seseorang atau kelompok orang dalam organisasi. Sesuai dengan wewenang dan tanggung jawab masing - masing, dalam rangka upaya mencapai tujuan organisasi bersangkutan secara legal, tidak melanggar hukum dan sesuai dengan moral maupun etika. Hal ini telah dibuktikan dalam penelitian Ariayanti (2015), dan (Handayani dan Rasyid, 2015) dimana kinerja guru SD di Gugus 10 Kota Prabumulih berhubungan erat dengan profesionalisme guru dan budaya organisasi di sekolah, dan kondisi ini memiliki persamaan dengan tempat yang lain. Hasil penelitian ini di dukung juga oleh penelitian yang dilakukan oleh Rohma et al (2020) dan Murkatik et al (2020). 
Dari perspektif sosiologis profesi adalah suatu pekerjaan yang mengatur dirinya melalui suatu latihan wajib dan sistematis dan disiplin kesejawatan yang didasarkan atas pengetahuan teknis spesialis, memiliki orientasi pelayanan dan bukan keuntungan serta dijunjung tinggi melalui kode etiknya (Alma, 2010) sehingga seorang guru dinyatakan profesionalisme. Selanjutnya budaya organisasi sekolah yang kondusif merupakan persyaratan bagi terselenggaranya proses belajar mengajar yang efektif (Handayani dan Rasyid, 2015). Pengaruh profesionalisem guru dan pengaruh budaya organisasi di sekolah merupakan dua variabel yang berpengaruh secara simultan terhadap kinerja guru SD di Gugus 10 Kota Prabumulih.

\section{SIMPULAN}

Terdapat hubungan signifikan antara kompetensi professional dengan kinerja guru, khusunya guruguru SD di Gugus 10 Kota Prabumulih. Hubungan berada dalam kategori sangat kuat $(r=0,886)$ dan signifikan $(\mathrm{sig}=0,000<0,05)$. Terdapat hubungan signifikan antara budaya organisasi di sekolah dengan kinerja guru SD di Gugus 10 Kota Prabumulih. Hubungan ini berada dalam kategori sangat kuat $(r=0,886)$ signifikan (sig $=$ $0,000<0,05)$. Terdapat hubungan signifikan antara kompetensi profesional dan budaya organisasi dengan kinerja guru SD di Gugus 10 Kota Prabumulih. Secara simultan hubungan ini berada dalam kategori sangat kuat $(r=0,930)$ signifikan (sig $=0,000<0,05)$.

\section{UCAPAN TERIMA KASIH}

Ucapan terima kasih diberikan kepada Kepala Sekolah dan Guru Sekolah Dasar Negeri Gugus 10 Kota Prabumulih. Terima kasih juga kepada semua pihak yang membantu penulisan dan penerbitan jurnal ini.

\section{DAFTAR PUSTAKA}

Alma, Buchari. (2010). Guru Profesional. Bandung: Alfa Beta.

Ariayanti, Nel (2015). Pengaruh Budaya Organisasi Terhadap Kinerja Pegawai. Jurnal Manajemen \& Bisnis 14(02).

Asvio, N., Yamin, M., \& Risnita. (2019). Influence of Leadership Style, Emotional Intelligence and Job Satisfaction toward Organizational Commitment (Survey at SMA Muhammadiyah South Sumatera). International Journal of Scientific \& Technology Research 8 (8).

Barnawi., \& Arifin, M. (2014). Kinerja Guru Profesional. Yogyakarta: Ar Ruzz Media.

Fattah, A. H. (2019). Kepuasan Kerja dan Kinerja Pegawai (Budaya Organisasi, Perilaku Pemimpin, dan Efikasi Diri). Yogyakarta: Elmatera.

Handayani, T., \& Rasyid, A. A. (2015). Pengaruh Kepemimpinan Kepala Sekolah, Motivasi Guru, dan Budaya Organisasi terhadap Kinerja Guru SMA Negeri Wonosobo. Jurnal Akuntabilitas Manajemen Pendidikan 3(2).

Majid, A. (2005). Perencanaan Pembelajaran. Bandung edisi revisi: Remaja Rosdakarya.

Murkatik, K., Harapan, E., \& Wardiah, D. (2020). The Influence of Professional and Pedagogic Competence on Teacher's Performance. Journal of Social Work and Science Education, 1(1), 58-69. Retrieved from https://ejournal.karinosseff.org/index.php/jswse/article/view/10

Raharjo. (2016). Kinerja Guru Profesional. Yogyakarta: Ar Ruzz Media.

Rohma, S., Harapan, E., \& Wardiah, D. (2020). The Influence of School-Based Management and Teacher's Professionalism toward Teacher's Performance. Journal of Social Work and Science Education, 1(1), 13-23. Retrieved from https://ejournal.karinosseff.org/index.php/jswse/article/view/6

Saputra, D. S. (2011). Hubungan antara Kompetensi Profesionalisme dengan Kinerja Guru di SMA XXX Tangerang. (Online). Psikologi, 9(2). (http://download.portalgaruda.org/article.php?article=94837\&val=4564, Agustus 2016).

Suharsaputra, U. (2018). Supervisi Pendidikan: Pendekatan Sistem BerbasisKinerja. Bandung: Refika Aditama. Suhayati, L. Y. Supervisi Akademik Kepala Sekolah, Budaya Sekolah, dan Kinerja Mengajar Guru. Jurnal Administrasi Pendidikan UPI, Volume XIII, 1 Oktober 2013.

Sutrisno, E. (2019). Budaya Organisasi. Jakarta: Predanameida Froup.

Suwarto, F. X., \& Koeshartono. (2009) Analisis Faktor yang Berpengaruh terhadap Kinerja Guru Sekolah Menengah Kejuruan. Jurnal Manajemen Sumber Daya Manusia.

Tobari., Kristiawan, M. \& Asvio, N. (2018). The Strategy of Headmaster on Upgrading Educational Quality in Asean Economic Community (AEC) Era. International Journal of Scientific \& Technology Research 7 (4). 